Тања Фрањо Гаев*

Филолошки факултет

Универзитета у Београду
821.161.2.09 Шевченко Т. Г.

doi 10.18485/analiff.2015.27.2.2

\title{
ПОЕЗИЈА ТАРАСА ШЕВЧЕНКА У СРПСКОМ ПРЕВОДУ
}

\begin{abstract}
Име украјинског песника романтичара, Тараса Шевченка, у српској култури први пут се појављује 1868. године у часопису Вила, убрзо после песникове смрти, уз прве преводе његове поезије на српском језику. Поетско стваралаштво Шевченка у српском преводу периодично је представљано у различитим часописима до 1896. године. Готово читав век Шевченко је био препуштен забораву. На српској књижевној сцени поново се појављује 1969, објављивањем збирке Кобзар и представљањем нових превода Шевченкове поезије, који су поново објављивани 1970, 1980, а у међувремену су им се придруживали нови 1979, 1994, 1999. И та традиција се наставља 2002, 2006. и траје до данас. О Шевченку се пише, говори, организују се књижевне вечери, његово стваралаштво се тумачи. У раду представљамо поезију Шевченка у српском преводу, његове преводиоце, њихово разумевање мотива Шевченкове поезије и песничке мисли и њихове највредније преводе, који виртуозно преносе суштину изворника на украјинском језику. Захваљујући преводима великана српске поезије можемо да читамо и разумемо песме најпознатијег украјинског песника на матерњем језику, али и да схватимо становишта, мотиве и тежње самог украјинског романтизма.
\end{abstract}

Кључне речи: песник, Тарас Шевченко, украјински, романтизам, српски, превод, култура преводилац, Кобзар

Тарас Шевченко (1814 - 1861) централна је личност украјинског књижевног процеса XIX века. Био је песник, сликар, филозоф демократа и револуционар. Његово стваралаштво у украјинској књижевности учврстило је заједничке демократске вредности и уздигло ју је на ниво водећих светских књижевности. У својој поезији Шевченко се окреће темама, проблемима и идејама (социјалним, политичким, филозофским, историјским, уметничким), који пре њега нису разма-

tanja.gaev@fil.bg.ac.rs; scienciaipsa@gmail.com 
трани у украјинској књижевности, или су разматрани превише стидљиво и социјално ограничено. Обогативши украјинску књижевност новим животним темама и идејама, Шевченко је постао иноватор и у потрази за новим уметничким формама и средствима. На књижевну сцену ступа у време процвата словенског романтизма, када се у Украјини формира разноликост овог правца, који је карактеристичан за недржавне нације (украјинску, белоруску, српску, словеначку) и близак је национално-ослободилачким тежњама нација и њиховом препороду. За Шевченка је сваки педаљ земље Украјине говорио о прошлој слави и прошлој трагедији, чије су последице биле садашње ропство народа, не само политичко и економско, већ и духовно - чврсто укорењено осећање националне неправде. Као и народне думе и песме, Шевченко опева двестагодишњу јуначку историју козаштва са њеном бурном енергијом, упорношћу, храброшћу и самопожртвованошћу, заједничким циљем, који је све ујединио, а то је био обавезујући племенити, правични циљ - заштита народа од страних освајача и ослобођење сужања. Јунаштво и мучеништво слободољубивог народа постали су главна обележја Шевченкове слике Украјине, његовог националног мита, који је песник стварао већ у раној лирици и у историјским поемама.

У српској култури име Тараса Шевченка и његовог стваралаштва познато је од 1868. године, када су објављени први преводи његових песама. Од 70-90-их година XIX века започиње први талас рецепције Шевченковог стваралаштва, а први преводиоци поезије највећег украјинског песника романтичара били су Владимир Николић: Завети, Неофитии, Рубаи // Вила 1868, Ђура Јанковић: Песмица // Зора 1869, Окица Глушчевић: Сан и Леше gани и ноћи оgлећу // Гусле 1886, Јован Грчић: Чини // Јавор 1877, Жарко Радонић: Роgила је мене матии... // Јавор 1887. и Драгутин Илијћ: Иван Пиякова // Босанска вила 1890. и Преg освитиом // Бранково коло 1896. Други талас рецепције уследио је читав век касније, тачније, 70-90-их година XX века, објављивањем збирке песама Тараса Шевченка Кобзар 1969. (поновљено издање 1980.), у коју су уврштени нови преводи Љубомира Симовића, Десанке Максимовић, Сергеја Сластикова и Јованке Хрваћанин. Јованка Хрваћанин своје преводе Шевченкове поезије објављује у часопису Ток 1970, Миодраг Сибиновић у Кьижевним новинама 
1994., Радослав Пајковић у оквиру своје Анйолойије украјинске йоезије 1979. и Лука Хајдуковић у својој збирци Хучи Дюейар широки 1999. Прва деценија ХХІ века обележила је последњи, најновији талас рецепције Шевченковог стваралаштва објављивањем његове поезије у преводу Миодрага Сибиновића, најпре у Анйолойиј украјинске иоезије XVI-XX век 2002., а затим и 2006. године, заједно са већ поменутим преводиоцима првог и другог таласа рецепције, када из штампе излази последње издање Кобзара, паралелено на украјинском и на српском језику.

Као први преводилац Шевченкове поезије на српски језик опробао се Владимир Николић. Песме Завей, Неофитии и Рубаи (Хустиина) светлост дана угледале су 1868. у часопису Вила, за чијег уредника, Стојана Новаковића, украјински књижевни процес није био непознаница. Новаковићу браћа Олександр и Осип Барвински, са којима је водио активну преписку, шаљу дела Тараса Шевченка, „Познатог свему Словенству, изузевши нас, Србе“. Уредништво Виле (1868: 274) уз преводе даје коментар „сила се поезије Шевченкове не може познати док се добро не познаје нарав, положај и живот народа његова, који је њему био познат боље но икоме, јер изашавши између спахијских кметића, сам је на себи најбоље познао муке народ-

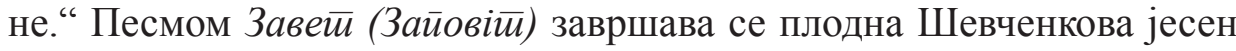
1845. године, а у преводу на српском први пут је објављена 7 година после Шевченкове смрти. Песму која почиње стиховима Кag умрем, сахранийе ме на српски језик, поред Владимира Николића превели су Окица Глушчевић (под псеудонимом Г) (Завей // Час, 1885), Десанка Максимовић (Порука // Козбар, 1969, 1980, 2006.), Радослав Пајковић

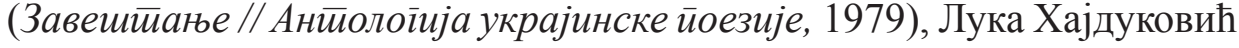
(Завети // Хучи Дюейар широки, 1999) и Миодраг Сибиновић (Ойорука // Анйолоїија украјинске йоезије XVI-XX век, 2002).

Шевченко је у песми која представља његово лично завештање, односно, завет сопственом народу употребио познати жанр «споменика» из дуге књижевне традиције, написавши песму новог жанра - поетску опоруку. Песник романтичар, али и бивши кмет, сада револуционар, тражи од свог народа да га сахрани Тамо на моіили / У нашојзи Украјини (В. Николић), Усреg стиейа широкијех / Украјине моје миле (О. Глушчевић), йамо усреg стиейе, / усреg стиеие нам широке, / 
Украјине лейе, (Д. Максимовић), Тамо у мойили / Среg сииейе йреgивне / На милој Украјини. (Р. Пајковић), На хумке висини, / Посреg сииеиее, ој широке, / У милој Крајини (Л. Хајдуковић), Да ме іруgи ириме / Наше леие сииеие / Дивне Украјине. (М. Сибиновић).

Водеће обележје Шевченкове поезије нераскидиво је јединство његовог лирског “ја“" и свенародног „ми“. Ни после смрти његова душа неће напустити родну груду и неће се смирити док је рођени народ поробљен. Ове идеје и осећања словенског романтизма посебно долазе до изражаја у преводима В. Николића и О. Глушчевића, који су сами трпели јарам и живели у ропству, и њихов позив на устанак сопственом народу обојен је националном тежњом слободи.

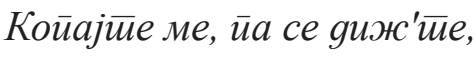

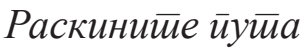

Хај слобояа нек' је врашком

Крвљу обасуйа! (В. Николић)

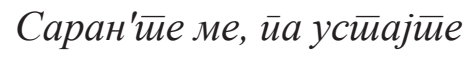

И лание разбите,

И крвничком злобном крвљу

Слобояу йолитее! (О. Глушчевић)

Својим пореклом и размишљањима Тарас Шевченко је одговарао схватањима Окице Глушчевића $(1858-1898)$. Шевченка су из кметства откупили руски сликари за 2.500 рубаља, док Глушчевић бежи од феудалца Селмановића, чији је чивчија био, зато што није могао да се откупи. Блиске су и судбине Шевченка и Глушчевића. Шевченко је прогоњен и по казни отеран у војску, док је Глушчевић теран и прогањан и у родитељском дому у Каменој Гори и у школи у Београду. Шевченкове песме, штампане само у иностранству, које својим лирским и романтичарским стилом говоре о борби украјинског народа за слободу и ослобођење, националне по песничким облицима а револуционарне по садржини, биле су узор Глушчевићу за националну борбу Срба и његовог родног краја. Његова родна груда притиснута јармом чекала је ослобођење од турског ропства. Глушчевић је сматрао да га на исправан пут могу упутити само интелектуалци и вође, који морају бити национални и револуционарни. Глушчевић је до краја свог живота остао национални борац са револуционарним схватањима, те му је узор за ту борбу, поред Светозара Марковића и његове Србије на истиоку, био и украјински песник Тарас Шевченко. Глушчевић постаје „близак“ Шевченку, кога је изузетно пошто- 
вао и преводио. Поред Завети $а$, превео је још две Шевченкове песме, објављене у Гуслама: Сан (1886: 3-7, 18-27) (под псеудонимом Белезис), и Лейе gани и ноћи оgлећу (1886: 17) (под псеудонимом Лара).

Београдски часопис Зора такође је подржавао идеје словенског романтизма, па је убрзо после смрти „највећег сина Украјине“ у преводу Ђуре Јанковића (1851 - 1875) објављена Шевченкова Песмица (Нащо мені чорні брови) (1869: 155). Песма је први пут објављена у збирци Кобзар 1840. и представља варијацију народних мотива девојачке усамљености и сиромаштва, које је Шевченко најактивније развијао у песмама из периода изгнанства.

У преводу даровитог песника Јована Грчића (иницијали Г-ћ) (1846-1875), кога са Шевченком повезује последња жеља да своје кости остави у месту свога рођења, у часопису Јавор (број 22 од 29. V 1877: 681-684; број 23 од 5. VI 1877: 713-716) објављена је Шевченкова песма Чини (Причинна), која осликава светску романтичарску традицију баладе. Сиже песме је народни, смрт девојке, која умире не дочекавши вољеног да се врати, а све то наговештава слика природе: опис олујне ноћи и обале реке, на којој је јунакиња, представљене помоћу типичних романтичарских ликова. Јунакиња баладе у којој је описана бурна ноћ је млада девојка, која, омађијана чинима врачаре, лута по ноћи поред Дњепра тражећи свог драгог, који јој је при одласку обећао да ће се вратити. Око ње под дрветом окупљају се речне виле и успављују је. Ујутру наилази на коњу млад козак, њен драги, и, видећи да она више није жива, и сам се убија. Грчић је у свом преводу у потпуности дочарао атмосферу изворника и у духу српског романтизма дубоко саосећа са несрећном девојком, сиротицом, молећи Бога да јој подари више среће.

Драгутин Или(j)ћ (1858 - 1926), син песника Јове Илића, а старији брат Војислава Илића, за време првог светског рата, новембра 1914. одлази у Русију да би водио пропаганду о борби Србије. У Одеси учествује у раду на прикупљању југословенских добровољаца за Добруџу, али се упознаје и са стваралаштвом украјинског песника. Свој превод Шевченкове песме Преg освитиом објавио је 1896. године (број 37 од 12/24. IX 1896:1165) у часопису Бранково коло, у ком је био један од уредника. 
Други талас рецепције Шевченковог стваралаштва започиње 1969. (издање је поновљено 1980. латиничним писмом), читав век касније у односу на први талас, објављивањем збирке песама Тараса Шевченка Кобзар у избору, редакцији, напоменама и поговору Петра Митропана, у коју су уврштени преводи Љубомира Симовића (Размишььање, Мисли, За вечийу усйомену на И. Койљаревскої

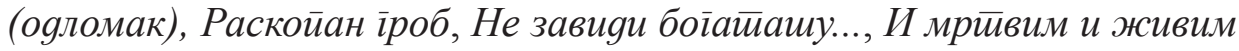
и нерођеним земљацима мојим у Украјини и ван Украјине - моја

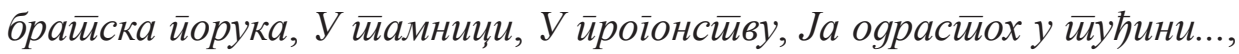
Такозвани добри љуяи..., Збої чеїа си йочрнела.., Не обузме жалосй мене..., Да л' несрећа, gа ли бољка..., Никаg нећу иоклекнуиии..., Подражавағе срискком, Не, не ройћем ја на Боїа..., Требало би gа ирестианемо...), Десанке Максимовић (Иван Пиякова, Мисли моје, бриіе моје.., Ияу gани, иролазе ноћи..., Порука, Мени је све јеgно gа ли ћу..., Да ли ћемо се оиети срестии..., Сунще йаgа за йамне йланине...,

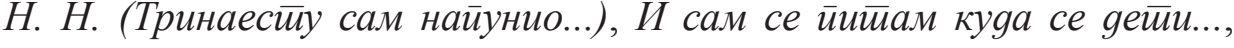
Би ли ил' не у стираху стиала..., Музика свира, болно јечи..., Прошла су ме млаgа лейа...), Јованке Хрваћанин (Вишње у извейу йокрај куће..., Сан, Зар немам, мајко, ие чарне очи..., Тече воgа оg јавора..., Пролази gан, иролази ноћ...), Сергеја Сластикова (Не савија ветиар іране..., Каg би іосӣоgичићи знали... и Не ваља ни овgе ни ииамо!...), заједно са старим преводима из XIX века. Митропан уз старе преводе објашњава да је интересовање за Шевченка у српској култури трајало до почетка Првог светског рата, после чега Шевченко ишчезава са видика наше књижевности. Митропан хронолошким редом наводи неколико заборављених превода Шевченкових дела на српски језик из старих часописа, како би у историјском пресеку илустровао који пут је прешло преношење идеја и мелодија стваралаштва великог украјинског песника. Елегијом Мисли моје, бриіе моје... (Думи мої, gуми мої..) (превод Десанке Максимовић, 1969: 3-6), написане као програмска песма и лирски увод почињао је садржај првог издања Кобзара, штампаног 1840. године у Петербургу на украјинском језику, где први пут у новој украјинској поезији, уопште, упечатљивија постаје романтична слика лирског јунака песника с аутобиографским моментима сопствене судбине (сиромаштво, усамљеност, туђина) и јасно дефинисаним поетским темама које су бринуле Шевченка: 
лирска тема љубави и јуначка тема козачке славе, односно сопствени стваралачки програм.

Децио, моје миље!

Заштио вас неїовах, зашито вас заливах?

Каg ја зайлачем, хоћу ли светиа gиьем

коїа расиилакай? Можgа залуд не снивах. (Мисли моје, бриіее моје...)

Десанка Максимовић (1898 - 1993), велика српска песникиња убраја се у најплодније преводиоце Шевченковог стваралаштва. Као дипломирани филолог светске књижевности, опште историје и историје Филозофског факултета у Београду добро је познавала руску, словеначку, бугарску и француску књижевност и повремено се бавила превођењем, махом поезије, са језика поменутих књижевности. Изврсним песникињиним преводима са руског језика допринео је Сергеј Сластиков (Калужанин) (1896-1976), руски емигрант, глумац и песник, супруг Десанке Максимовић, који се и сам уврстио у преводиоце Шевченкове поезије.

Шевченко и Десанка Максимовић своје песме називају својом децом, негују их, усавршавају и посвећују им највредније што имају, а то је таленат песника испуњен љубављу и најискренијим осећањима. Обоје певају о љубави према свом завичају, родној груди и сународницима који на њој живе.

Иуитее на Украјину, сииеие Украјине, ко сирочаg, а ја остиах овgе gа йоіинем.

Тамо ћеие наћи љубав, реч ирисну, ласкаву.

Тамо ћейе наћи иравgу, а можса и славу.

Приірли је, моја нано, моја Украјино,

моју gеиу наразумну,

као своїа сина. (Мисли моје, бриїе моје...) 
Д. Максимовић препознаје срећу, или усуд, „доля-недоля“, један од основних мотива Шевченкове поезије, коју је сам песник добро упознао, изједначавајући своју худу срећу са трагичном судбином сељака роба принуђеног да свој век проживи служећи својим угњетачима и потчинивши га њиховој самовољи. Попут црвене нити она прожима Шевченков живот, а то у изузетном преводу Д. Максимовић остаје сачувано на српском језику

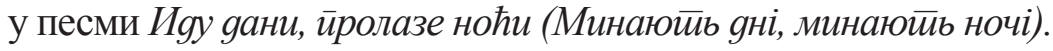

Срећо, где си? Где си, срећо?

Гласа ниоткуд.

Не можеш ли удес добар,

дај ми, Боже, худ!

Али, ма каква судбина била, треба је проживети на најбољи могући начин, јер је најгоре проживети живот узалуд и не оставити никаквог трага.

Зло је йасиии у окове,

мретии заробљен,

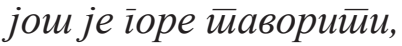

снова бииии илен,

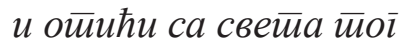

не остиавив йраїа.

Д. Максимовић доследно преноси и остале теме које су срж Шевченковог стваралаштва: тема о горчини љубави над којом лебди фатум туђе власти у преводима песама Мени је све јеgно gа ли ћу... (Али ми није свејеgно / ако Украјину зли љуяи / уљушкају, йокраяу у сну / и ако се у ватири ирробуgи... / O, није ми све јеgно за юу), И сам се

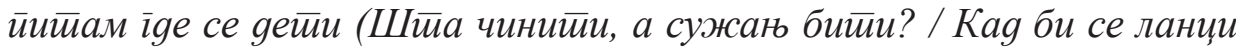
gали іристии, / іризао бих йолако), Да ли ћемо се оиети срестии (Нек је

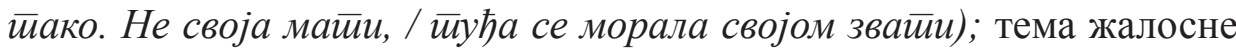
судбине младости која вене у условима бесправља у преводима песама Прошла су ме млаgа лейа (Осйани самаи исйоg сииреје / gок ие и наgа не исмеје...), Музика свира, болно јечи (...Срие луgо / ваљgа жали шито узалуяно / и суморно млаgости иройраћих), Би ли ил' не у

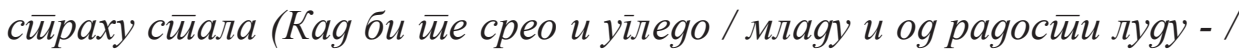
срећу своју неїgашъу хуgу - / савлаgо би ме йлач и бол). 
Још један велики српски песник, Љубомир Симовић (1935), у својим преводима верно осликава теме које су „мучиле“ Шевченка: одсуство слоге и однародњавање интелигенције од „нижег сталежа“: Не завияи боїайаму (Не завияи боїайаму, / јер боїайи не зна / ни за яружбу, ни за љубав, / без злайних ииинеза); тужна размишљања о људима, неправди, животу и његовим вредностима, које се често изопачују: Такозвани добри љуgи (Без злойвора некако се / ироживеии

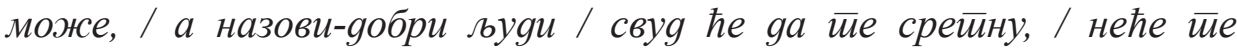

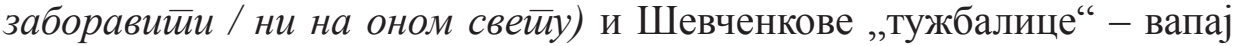
сужња из прогонства и заточења: У йроїонстиву (Боже! Хоћу ли gуі̄o, u

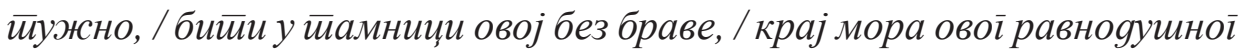
( бол gа болујем?...)

Јованка Хрваћанин (1899 - 1987), дипломирани филолог, преводила је много, највише са словенских језика, а у поезији раног Шевченка препознала је јак утицај народне поезије која прожима песникову поезију народном симболиком (слике гроба, ветра, судбине, мора, тополе, црвене оскоруше): Тече воgа оg јавора (Уgика се рујна іоряи, / јавор йоgмлађује, / а око њих из врбака / шум се лишћа чује); Три се ииуйа, ирри широка (Јасени се не иримише / ни йойола бела, / усахнула ирри јавора / удика увела). Касније, у Шевченковом стваралаштву доминирају симболи, метафоре, персонификације сила природе и апстрактних појмова, асимилације, поређења и епитети народног песничког порекла.

Радослав Пајковић у Београду 1979. објављује Анӣолоїију украјинске йоезије, прву такве врсте у српској култури, чијим је избором, предговором, белешкама и преводом с украјинског језика, представио стваралаштво 31 украјинског песника и писца, обухвативши период украјинске поезије од скоро два века, почев од средине XVIII века закључно са крајем XX века. Р. Пајковић нас кроз предговор води кроз историју уметничке поезије Украјине, скрећући посебну пажњу на класичну поезију у Украјини, која настаје крајем XIX - почетком $\mathrm{XX}$ века, а проистиче из народне поезије и почива на усменом народном стваралаштву. Овај период који је изродио велике песнике: Тараса Шевченка, Ивана Франка и Лесју Украјинку може се назвати златним веком песничких остварења у украјинској књижевности. Њихови стихови који и данас одјекују допринели су буђењу националне свести из ког је произашло «све оно вредно што данас постоји у 
украјинском бићу». Р. Пајковић преводи следеће Шевченкове песме: Н. Н. (Сунце захоgи, іоре хлаяују..), Зарасли су иууиии иирњем..., У gолу

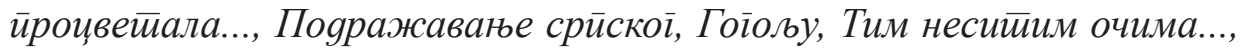
Монашка химна, Муза и Завешйање. Поред већ наведених мотива, који чине суштину Шевченкове поезије, Р. Пајковић дочарава и благи утицај природе која стишава душевне незгоде: У gолу ироивейала... (У gолу ироиветиала / Калина ирвена / Као gа се насмејала / Девојка малена), као и надахнуће које песнику шаље Муза (Ти сестиро Феба млаgейна!... О, чаробнице моја! / мени си увек иомаїала / И свуgа наgїлеgала). Лука Хајдуковић (1937-2010), магистар филолошких наука и преводилац с руског и украјинског језика, објавио је у Београду 1999. збирку поезије Шевченко, Франко, Малањук, Хучи Дюейар широки паралелно на украјинском језику и у избору и преводу на српски језик, уз текстове о песницима. За превод поезије тројице украјинских песника Удружење књижевника Украјине доделило је Луки Хајдуковићу Међународну награду „Иван Франко“. У Увоgној речи Л. Хајдуковић наводи: „Растужује и опомиње истина: украјинска поезија није довољно превођена на српски језик. Оно што је, захваљујући мару малобројних преводилаца, из ње пренесено у културу Срба, премало је да би било у сразмери са њеним значајем, а још мање да би проширило видике српског читалаштва.“ < ..> „На маркантној путањи украјинске поезије од појаве Кобзара (1840) до наших дана Шевченкова лира се препознаје као архетипска парадигма <..>, што књизи Хучи Дюейар широки даје конкретну садржину.“ Хучи Дюейар широки

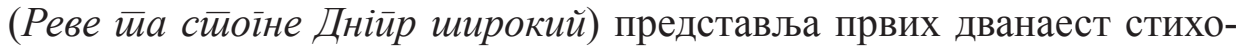
ва познате Шевченкове баладе Чини (Причинна), објављене у првој Шевченковој збирци поезије Кобзар (1840). Ову песму Шевченко је, по сопственим наводима, написао још као кмет 1837. године.

За Шевченка Л. Хајдуковић наводи да је песник једне књиге Кобзара. „Дубока национална освешћеност и ослонац на језичко-поетска средства народне књижевности постали су после њене појаве алфа и омега украјинског песништва. Потоњи издавачи уносили су у њу све што се из песникова пера оваплотило у стих“. У преводу Л. Хајдуковића објављене су следеће Шевченкове песме: Муза, Кайерина (Оوломак), Ту їgе Дюейар брежје своји..., Мисао, Три се йуйа, ој иирока.., Вишњик малени йореg куће.., Ој, имам, имам йламне очице..,,

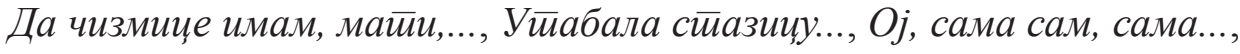


Гоїољу, Пояражавање 11. йсалму, Молийва, Зачарај ме, чаробниче..,

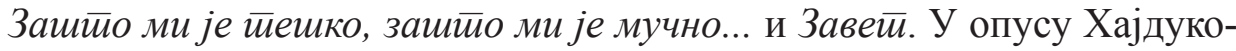
вићевих превода посебно треба истаћи одломак из поеме Каиеерина, којом је Шевченко представио усамљену девојку која тражи љубав и постаје покритка - обешчашћена девојка - осрамоћена кћер, коју родитељи избацују из дома, зато што је прекршила природни закон рода, који је штитио породицу као основу друштва, основу нације, гаранцију њеног постојања. Катерина је изопштена, прогнана и осуђена на пропаст. Схватајући то и уздижући мајчинство и породицу као највеће благо људског живота, Шевченко је дубоко саосећао и веома је патио због трагедије покритке и њеног детета копилета. Оплакујући унакажени цвет - млади живот чисте девојке лепотице, песник уздиже идеал природног човека, супротстављен варљивим вредностима цивилизације експлоататора, представљених кроз туђинца официра, човека другог менталитета, туђег морала.

Последњи, најновији талас рецепције Шевченковог стваралаштва започет је 2002. објављивањем у Бања Луци Анйолойије украјинске йоезије XVI-XX век под насловом У инай ветировима у избору и са предговором, коментарима и преводима Људмиле Поповић и са поговором и преводима Миодрага Сибиновића. У ову антологију уврштено је 67 украјинских песника, чија су дела представљена паралелно у оригиналу на украјинском језику и у преводу на српски језик, уз све потребне коментаре о делима, ауторима, претходним преводиоцима и изворима у којима су ти преводи објављени. За превод наведене антологије украјинске поезије професору Филолошког факултета у пензији, Миодрагу Сибиновићу (1937), додељена је украјинска Међународна награда «Иван Франко» 2004. године. У антологији су у преводу професора Сибиновића објављене следеће Шевченкове песме: Мисли моје, мисли моје..., Пролазе gани, ияу ноћи..., Оиорука, Н. Н. (Тек ми је йринаести замакло), Подражавање 11. йсалма и Сан (оgломак из йоеме). Поред одломка из поеме Сан, у Кьижевним новинама 1994. објављени су и преводи Зачарана, O, sуgи! љуgи несрећници..., И мрйвим и живим...

Посебно истичемо превод поеме Сан (Сон), написане 8. јула 1844. године у Санкт-Петербургу, објављене у збирци Три літиа. Поема почиње лирским размишљањима аутора приповедача. Свако има 
срећу своју и свој $\bar{u} у \bar{u}$ бескрајни: један зида камене зидове, други их руши, трећи се труди да освоји туђу земљу, један гули ближњега сво-

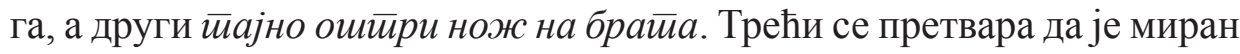
и да поштује Бога, док само чека прави час ga $\bar{u} и$ к сриу кание йустии. Неки добри и раскошни све храмове зида и хвали се љубављу према отаџбини, ga к'o воgу крв јој йочи. А сви други ћуте к'о јагњад, јер тако ваља, јер на небу ни Госйоgа нема! Ујармљени људи умиру несрећни, чекајући рај на ономе свету. Али залуд, раја нема. Аутор моли све да се призову памети, да се сете, да су и сиромашни и богати само јеgно истио - Аgамови знанци. Тако размишља приповедач, док се као пијан враћа са пира. Код куће леже да спава и усни сан који би свакога зачудио. Уснио је као да над земљом лети сова, а он за њом. Лети и опрашта се са светом, са својим крајем у коме људи испаштају, муче се. Ноћу се покритка с копилетом вуче, одрекли су је се родитељи и не примају је туђи људи, а господичић који ју је обешчастио, појма о томе нема и с другом се љубака. Нико не зна колико ће на овоме свету још владати џелати. А Бог, уколико и види кроз облаке људске сузе и несрећу, не помаже људима. У родном крају нема среће, и приповедач одлучује да потражи рај, макар на крају света. Тешко му је да остави мајку Украјину, али му је још теже да гледа њене сузе и беду. Полетевши за совом, дошао је до земље покривене снегом (Сибира), око мене іора и рииивина, їласа љуяскої нема. Чује се како негде испод земље звецкају ланци. Испод земље, као из гроба, почеше излазити не мртваци, већ живи људи оковани у ланце, робијаши. Они испод земље копају злато како би залили незаситога (цара). Међу заробљеницима нису само злочинци и разбојници. Ту је и жигосани, револуционар окован у ланце, цар слободе, који храбро издржава све муке, не одричући се својих идеја. И поново приповедач лети изнад земље. Гледа одозго куће над путевима и градове са много цркви, а у другим градовима, као ждралови мирно уче реg москови. Затим види доле велики

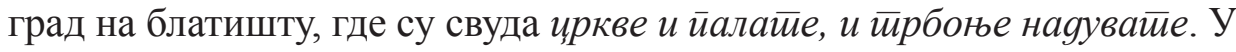
част цара Николаја I приређена је парада. Лакеј тражи мито да кришом одведе приповедача у царску палату. Али приповедач, одбивши његову услугу, постаде невидљив и сам се нађе у палати, где виде горду господу и цара и царицу. Приповедач се чуди да су песници шмокљани луgи поредили ову јадницу са богињом. Иза цара иде сва господа и труди се да стане што ближе цару и царици. Љути цар оша- 
мари свог најстаријег поданика, овај млађег, а затим се све настави ланчано, свако се труди да удари млађег од себе, док се туча не пренесе из царске палате на улицу. Приповедача зачуди што сви грађани то прихватише као царску милост и почеше радосно вриштати. Увече, када се утиша бука, приповедач оде да погледа престоницу и зачуди га jag и чемер, велелепни град на блатишту саграђен за велику цену. На једној обали реке чују се звона Петропавловске тврђаве, на другој је споменик Петру I: $O x$, йај Први расиеео је Украјину славну, $A$ Друїа (Катарина II) је йримлайила сиройу бескрајну. Приповедач се растужио, сетивши се тужне историје Украјине. На козачким костима саграђена је престоница Руског царства, а у тамници је убијен хетман Полуботко. Цар је гулио кожу Украјинцима како би од ње сашио себи плашт и у тој новој манйији подигао многе цркве и палате. Сунце зађе и приповедач виде други Петербург, град у коме људи тешким радом зарађују свој хлеб насушни. Међу чиновницима који журе у Сенат, он виде многе своје земљаке, који се одрекоше матерњег јези-

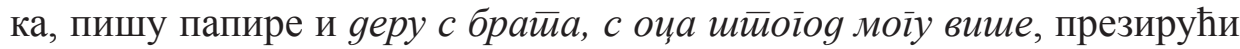
своју мајчицу Украјину. Приповедач одлучује да још једном погледа царске палате. Тамо виде гордог цара, попут медведа, који риче на господу, на чељад и на москове. А када од његове дреке сви пропадну у земљу, цар стиоји јаяник, сейно іллеgа йокунио іллаву... и уопште није страшан, налик на маче. Поїлеgах їа! - накараgа!... И смеј ме уgави! Чувши смех, цар се поново разљути и рикну на приповедача који се престрави и пробуди. Тако се завршава овај невероватни сан, чудо, које се усни само наказама и пијаницама: Таква чуgа... йо су снови / Само јурояива / Ил иичана.

Године 2006. у Новом Саду у издању Савеза Русина и Украјинаца Србије светлост дана угледао је Кобзар Тараса Шевченка у избору, редакцији и предговору Људмиле Поповић, паралелно на украјинском језику и у преводу на српски језик, за који би се могло рећи да је допуњено и проширено издање избора који је приредио Петар Митропан $(1969,1980)$. Свим претходним преводима из Кобзара Петра Митропана додати су подједнако виртуозни, често ненадмашни, преводи Миодрага Сибиновића. У најновији Кобзар укључени су преводи Луке Хајдуковића из збирке Хучи Дюейар широки и песма Молитива у преводу Тодора Дутине (1948 - 2007). Шевченко је Молийву написао последње године свог живота (1860). Дутина је у свом 
преводу веродостојно изрекао његову последњу жељу: А мени, Боже, на земљи / Даруј љубав, яушевни рај! И више нишйа ми не gај. У Кобзару су први пут објављени следећи преводи професора Сибиновића: Тойола (одломак), Гајgамащи (одломак), Уйойљеница, Шйо ми

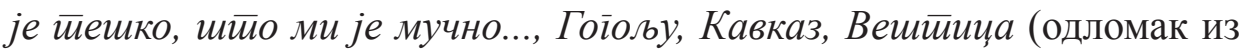
поеме), Косач, Кнейиња (одломак из поеме), N. N. (O иесме моје, о іласу худи...), Пољацима, Питиамо јеgни gруіе немо..., Бої је иза врайа gржао секиру..., За сунцем мали облак йлови..., Закукала кукавица..., Не ияући ноћу кући..., О Ускрс, не слами се.., Бројим у ройсииву яне и ноћи..., Суђаја, и Дан иролази, етио ноћи...

Посебно истичемо превод одломка из романтичарске јуначке историјске епопеје Гајgамаци, посвећене антифеудалном устанку против пољског кметства (1768) на Правобережној Украјини. У условима кметовске Русије поема у којој се велича народни устанак против социјалног, националног и верског угњетавања, доживљавана је као политичко дело. Идеје фолклора у коме живот човека још није раздвојен од живота природе налазе се у основи дела: метафора боја и банкета, крви и сетве, казне и вечере, смрти и забаве, у основи персонификације предмета и природних појава, психолошког јединства јунака са природом. Поема је прожета емоцијама ослободилачке борбе, садржи алузије, које су помогле читаоцу да схвати њен савремени социјално-политички подтекст. (... Љygu, љуgu! / Да л' ће ga вас каg уљуgи / Добро које већ иматее? / Чуgни, чуgни љуgи!)

Шевченко се уздизао на високом таласу националног препорода који је захватио читав словенски свет. Прошлости се обраћа ради буђења националног самопоштовања, свесности и утврђивања себе као народа са древном и јуначком историјом. Управо за будућност била је потребна јуначка слика Украјине, и не оне која се више никада неће вратити, већ оне која ће се тек родити у душама њених синова, који су гурнули у заборав злогласни дух понизности.

Шевченкова поезија права је поезија мисли, која је у истој равни са напредном социјално-политичком мишљу свог времена. Значај Шевченка у историји украјинске уметничке речи посебно је у томе што је он изузетно проширио тематске хоризонте украјинске књижевности, учинио ју је најважнијим фактором развоја друштвене свести, више него било који украјински писац, приближио је књижевност народу, који га је признао за свог песника и заштитника. 
Захваљујући изврсним преводима бардова српске поезије, почев од периода романтизма који је у српској књижевности био у свом највећем успону, до савременог нам времена, прве деценије XXI века, разумевању значаја и мотива Шевченковог стваралаштва, представљањима лика и дела најзначајнијег украјинског песника у часописима, антологијама, збиркама српске културе, повлашћени смо да се упознамо са највећим делом наслеђа поетског генија Тараса Шевченка на свом матерњем језику, готово ни у чему не остајемо лишени богатства и лепоте поетске мисли изречене у изворнику на украјинском језику.

\section{Извори:}

Босанска вила (1885-1914). Сарајево

Бранково коло (1895-1914). Сремски Карловци

Викно. Књига I (2004), Београд: Филолошки факултет у Београду

Вила (1865-1868). Београд

Гусле (1886)

Зора (1869). Београд

Јавор (1862-1863; 1877)

Книжевна реч (1951). Београд

Кьижевне новине (1978). Београд

Književne novine (1951: 2). Beograd

Nova Evropa (1939). Zagreb

Odjek (1975). Sarajevo

Пајковић Радослав (1979). Анйолойја украјинске йоезије, Избор, предговор, белешке и превод с украјинског од истог аутора, Београд: Петар Кочић

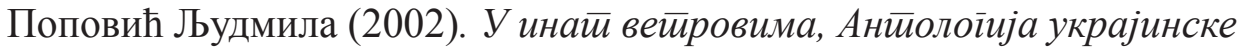
йоезије XVI-XX век. Бања Лука: Завод за уџбенике и наставна средства Републике Српске

Ток (1970). Прокупље

Tpaī (2007). Врбас: Народна библиотека „Данило Киш“

Час (1885). Београд

Шалипуровић Вукоман (1981). Окииа Глушчевић: живош̄ и pag, Београд: Нолит 
Ševčenko Taras (1969). Kobzar (Izbor), Izbor, prozni prevod, redakcija, napomene i pogovor Petra Mitropana, Beograd: Rad

Ševčenko Taras (1980). Kobzar (Izbor), Ponovljeno izdanje, Izbor, prozni prevod, redakcija, napomene i pogovor Petra Mitropana. Zrenjanin: Biblioteka „Žarko Zrenjanin“

Шевченко, Франко, Малањук (1999). Хучи Дюейар широки. Избор, превод, текстови о песницима Лука Хајдуковић. Београд: Завод за уџбенике и наставна средства

Шевченко Тарас (2006). Кобзар (Избор), Нови Сад: Савез Русина и Украјинаца Србије

Тања Фрањо Гаев

\section{Резюме}

\section{ПОЭЗИЯ ТАРАСА ШЕВЧЕНКО В СЕРБСКОМ ПЕРЕВОДЕ}

Имя украинского поэта романтика, Тараса Шевченко, в сербской культуре впервые появилось в 1868 г. в журнале Вила, вскоре после смерти поэта, вместе с первыми переводами его поэзии на сербском языке. Поэтическое творчество Шевченко в сербском переводе периодически представлено в различных журналах до 1896 г. Почти столетие Шевченко остался в небытие. На сербской литературной сцене он снова появился в 1969 г., изданием его сборника Кобзар и представлением новых переводов поэзии Шевченко, их переизданиями в 1970, 1980 гг., тем временем к ним присоединялись новые переводы в 1979, 1994, 1999 гг. Традиция продолжается в 2002, 2006 гг. и продолжается и сегодня. О творчестве Шевченко пишут, говорят, проводят литературные вечера, толкуют его творчество. В данной статье представляем поэзию Шевченко в сербском переводе, переводчиков его поэзии, их понимание мотивов поэзии и поэтической мысли Шевченко, также самые ценные переводы, которые добродетельно передают суть оригинала на украинском языке. Благодаря переводам великих представителей сербской поэзии мы можем читать и понимать стихи самого известного украинского поэта на родном языке, также понять точку зрения, мотивы и стремления самого украинского романтизма.

Ключевые слова: Поэт, Тарас Шевченко, украинский, романтизм, сербский, перевод, культура, переводчик, Кобзар 